\title{
THE ARCHAEOLOGY OF CANIA GORGE: AN OVERVIEW
}

\author{
CATHERINE WESTCOTT, IAN LILLEY AND SEAN ULM \\ Aboriginal and Torres Strait Islander Studies Unit, University of Queensland, \\ Brisbane, Queensland, 4072, Australia
}

\begin{abstract}
This paper presents a general overview of archaeological investigations in the Cania Gorge region, located on the western margin of the Gooreng Gooreng Cultural Heritage Project study area. It includes a physical description of the region and a brief outline of the cultural setting, before presenting a summary of archaeological investigations undertaken in the area.
\end{abstract}

\section{Introduction}

Cania Gorge is the focus of the inland archaeological investigations conducted under the auspices of the Gooreng Gooreng Cultural Heritage Project. The gorge is located $20 \mathrm{~km}$ north-northwest of Monto in Central Queensland, at approximately $24^{\circ} 40^{\prime}$ south and $151^{\circ}$ east. It lies on the eastern side of the Great Dividing Range, about $120 \mathrm{~km}$ from the coast, in the upper Burnett River Basin. Most of the gorge lies either in Cania Gorge National Park, Cania Station or in surrounding State Forest. The area is on the western boundary of land traditionally identified as the country of Gooreng Gooreng speakers at the time of European contact, bordering on Gangulu and WuliWuli countries to the west (Horton 1994; Williams 1981).

The gorge consists of dissected sandstone escarpments, covering an area of approximately 5,000 ha (Figures 1-2). It is a broad, shallow gorge, with Three Moon Creek, the main watercourse, flowing through open eucalypt woodland and edged by alluvial flats. Three Moon Creek is fed by tributaries flowing from side gullies. Some of these gullies and well-watered sections of the creek provide a moist, cool environment for ferns and dry vineforest. In 1979 the Cania Dam was built at the northern end of the gorge, regulating the flow of Three Moon Creek and dramatically altering local hydrological regimes and patterns of erosion and sedimentation.

\section{Physical Setting \\ Geology}

The Monto region exhibits a complex mixture of metamorphic, igneous and sedimentary rocks. The base of the Cania district sediments is derived from predominantly volcanic activity. It comprises Palaeozoic sediments, mainly cherts and submarine lava flows, overlain by andesitic and basaltic lavas (Dear 1959:98). In the Cania area, Permian sediments and volcanics are estimated to be $3,000 \mathrm{~m}$ thick. The beds consist of greywacke, siltstone, argilite, rhyolitic tuff, black calcareous mudstone, andesites and tuff (Malcolmson 1970:2). The youngest beds are Tertiary volcanic flows, mainly basaltic (Dear 1959:99). A cross-section of the substrate shows a number of broad, gently arched anticlines and synclines. The folds are cut by longitudinal high-angle thrusts and tensional cross-faults, resulting in extensive outcropping of all layers of rocks (Dear 1959:7; Malcolmson 1970:2).

\section{Climate}

The Cania district experiences a sub-tropical, subhumid climate, with long, hot, wet summers and mild, dry winters. The Three Moon Creek catchment area has an average rainfall of approximately $800 \mathrm{~mm}$, with about two-thirds occurring between November and April. Droughts are a regular feature of the district. Prior to the building of the Cania Dam, Three Moon Creek was prone to flooding during the summer wet season (Malcolmson 1970:Section 3-1; Smith and Kent 1993:5).

\section{Vegetation}

The vegetation of the Cania district has been significantly modified by recent non-Aboriginal landuse including grazing, mining and forestry. Selective ringbarking and clearing are generally confined to lower slopes and the valley floor. Fire is commonly used as a management tool (I\&WSC 1971). Alluvial soils adjacent to Three Moon Creek are chiefly clay and sandy loams. Timber cover is sparse and consists of riverine open forest, predominantly Queensland blue gum (Eucalyptus tereticornis) with sporadic gum-topped box (E. pilligaensis) and poplar box $(E$. populena). Forest blue grass (Dichanthium sericeum) is the dominant grass species on the alluvial flats (Malcolmson 1970:Section 4-4; Smith and Kent 1993:18), along with slender bamboo grass (Stipa verticillata) and kangaroo grass (Themeda australis) (I\&WSC 1971). Around the gorge, the soils are sandy clay loams with a sandstone and siltstone substrate. The undulating plains and dissected hills on top of the escarpment support open forest, mainly narrow-leaf ironbark (Eucalyptus crebra) and poplar box, with occasional silver-leaf ironbark (E. melanophoia), white gum ( $E$. platyphylla), pink bloodwood $(E$. intermedia) and Queensland blue gum, typical of Central Queensland's extensive sandstone belt (Smith 
and Kent 1993:21). At the base of the escarpments, areas of rainforest are found. Many of the plants from these areas have not been reported as growing elsewhere in the Burnett region (I\&WSC 1971).

\section{Fauna}

The building of Cania Dam and land clearing has disturbed or altered animal habitats in many parts of the gorge. Grazing of cattle (Bos taurus and B. indicus) continues in many parts of the gorge. Although no detailed studies have been undertaken in Cania Gorge, the nearby Kroombit Tops State Forest has been subject to limited fauna surveys (Schultz 1994) where similar species to those observed in Cania Gorge were reported. Four species of macropod inhabit the gorge, the eastern grey kangaroo (Macropus giganteus), whiptail wallaby (M. parryi), swamp wallaby (Wallabia bicolor) and the nocturnal rufous bettong (Aepyprymnus rufescens). The gorge has three large possum species, the common brushtail (Trichosurus vulpecula), mountain brushtail $(T$. canius) and ringtail (Pseudocheirus peregrinus). The gorge also has two monotremes, the common echidna (Tachyglossus aculeatus) and the platypus (Ornithorhynchus anatinus). The birds are typical of drier southeast Queensland open forest habitats, with little evidence for invasion by exotic bird species. Larger species of fish have succumbed to the environmental changes brought on by the building of the dam and competition from species introduced to stock the dam. Rainbowfish (Melanotaenia sp.) still inhabit Three Moon Creek. The one large native species of fish still present is the jewfish (Tandanus tandanus), but it is unclear if it is endemic or locally introduced.

\section{Cultural Setting}

The Burnett-Curtis area is traditionally associated with a group known variously as the Gooreng, Gurang, Koreng-koreng and Kooranga (Mathew 1910; Tindale 1974). People camped and travelled in groups of varying sizes, according to seasonal patterns. In historical times people regularly travelled from the coast to the hinterland, exploiting bush foods along the way (Williams 1981).

The Upper Burnett was traversed by Thomas Archer in 1848 and was settled by Europeans soon after (Johnston 1982:3). The original properties of Rawbelle, Dalgangal-Cannindah and Cania ran sheep until 1883, when cattle were introduced (Malcolmson 1970:Section 1-1). Pastoral expansion resulted in clashes with the Aboriginal owners of the area and the early years of settlement were characterized by continual conflict between the two groups. Aborigines raided settlers and their stock, while the pastoralists shot and poisoned the Aboriginal population (Williams 1981:6-8). During the 1850s, the Native Mounted Police helped to quell Aboriginal resistance, and by 1860 the Europeans had generally established control of the area (Denholm 1972:355356; Williams 1981:12-13).

The Cania area was mined for alluvial gold from the 1870 s until the early years of this century (de Havelland 1987:227-229). Mining activities were less disruptive to the Aborigines than pastoral settlement and, with Aboriginal resistance already reduced, Aborigines and miners enjoyed relatively good relations (Williams 1981:20-21).

Under the Aborigines Protection and Restriction of the Sale of Opium Act 1897, reserves were set up and some of the Aborigines from Gooreng Gooreng country were sent to Cherbourg (then Barambah) or Woorabinda (Williams 1981:24). This removal caused the separation of families, many of whom are still seeking reunions today. Aborigines not moved to reserves often attached themselves to the stations established on their traditional lands (Williams 1981:28).

The Aboriginal people in the Burnett-Curtis region today speak dialects which they identify as Gooreng Gooreng, Waka Waka or Wuli Wuli. There are many similarities among these dialects. Language is being recorded with the help of present-day speakers and is helping to maintain cultural continuity (Jolly 1994; Williams 1981:36-37).

Oral traditions among the Gooreng Gooreng are also being recorded. They include stories that tell of the Rainbow Snake, sorcery practices, drought and the search for water, as well as post-contact stories of massacre by Europeans (Clarkson et al. in prep.; Williams 1981:38-39). Aboriginal sites of significance have been identified by Williams (1981:37-40; see also Clarkson et al. in prep.), including carvings, art sites, natural formations and landscapes that are significant owing to their role in stories or historical events, or traditional or contemporary use. Engraved rocks removed from the Burnett River are in the process of being returned to the traditional owners (Ulm and Lilley 1996).

\section{Archaeological Surveys and Excavations}

Prior to the studies of the Gooreng Gooreng Cultural Heritage Project, Cania Gorge was unknown archaeologically apart from the incidental recording of one rock art site in the early 1980s and secondhand comments reported by Walsh (1984).

Systematic archaeological investigations in the Cania Gorge area were initiated in 1995 under the auspices of the Gooreng Gooreng Cultural Heritage Project to assess the archaeological research potential of the region, primarily to augment an understanding of sites in the region, until that time based on coastal 


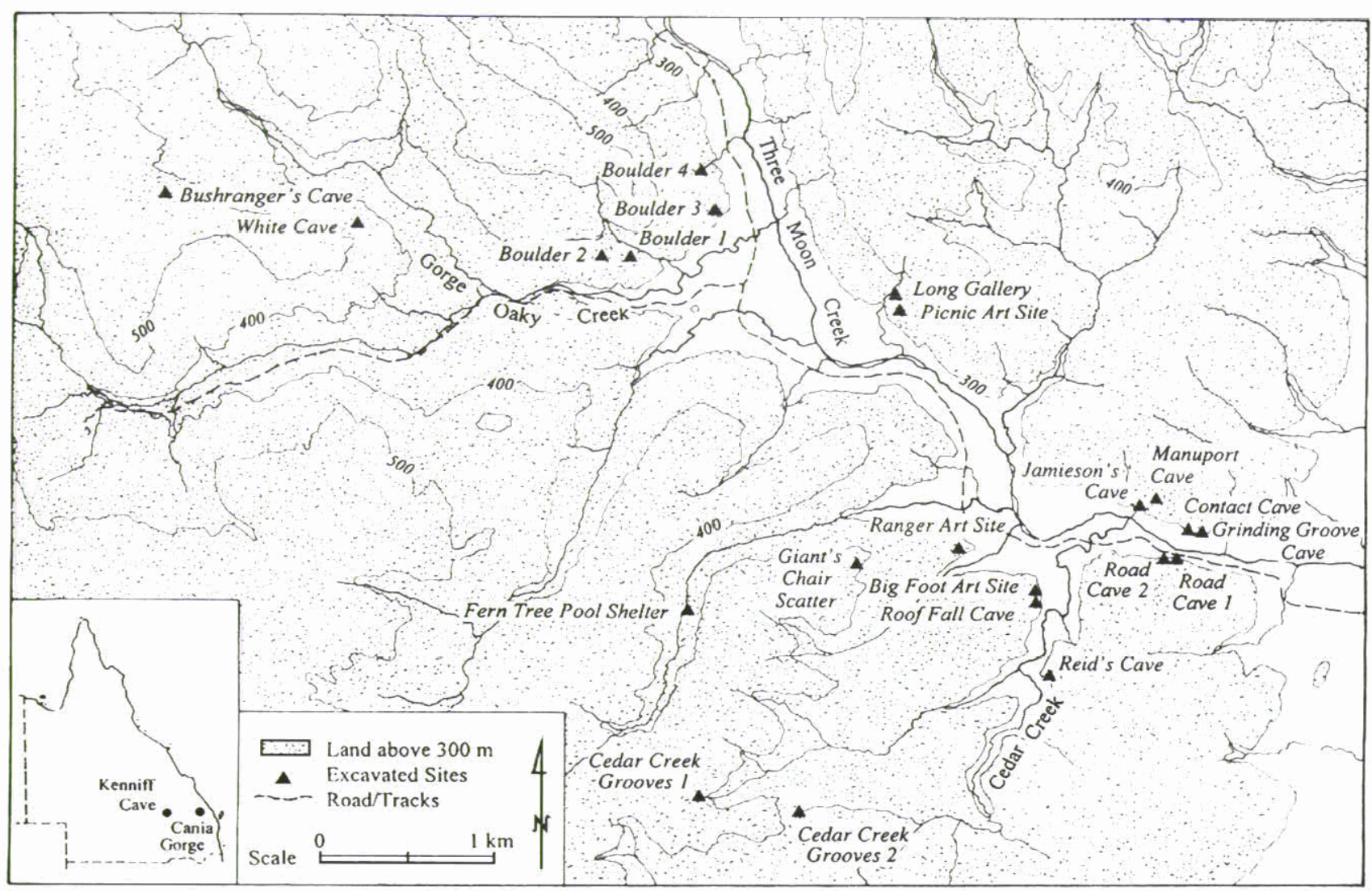

Figure 1. Southern Cania Gorge, showing recorded archaeological sites.

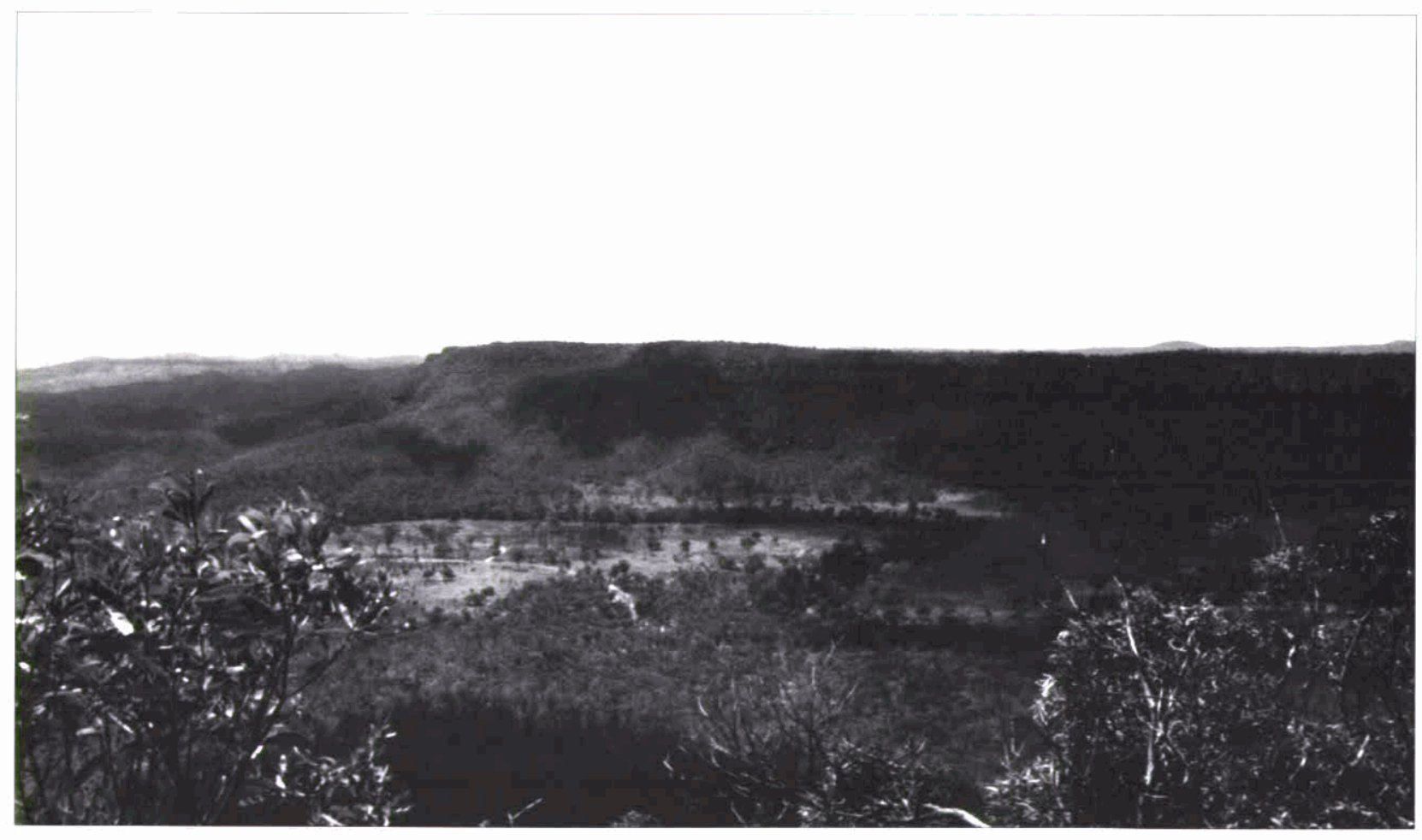

Figure 2. General view of Cania Gorge, facing north (Photograph: S. Ulm). 
sites (see Lilley and Ulm 1995). The initial surveys provided the basis for a subsequent program of test excavation which aimed to investigate questions concerning the nature, extent and antiquity of subsurface cultural remains and the age of the rock art. In total, 52 days of archaeological survey and excavation were conducted in the Cania Gorge area between July 1995 and July 1997.

\section{Survey Results}

Surveys in the Cania Gorge region resulted in the documentation of 23 Aboriginal cultural heritage places, 21 of which had not been previously recorded (Appendix A). The 'Site ID' in the first column of Appendix $\mathrm{A}$ is the Gooreng Gooreng Cultural Heritage Project file number. The 'CG' prefix stands for 'Cania Gorge'.

Surveys targeted the change of slope along the base of the escarpment where weathering is conducive to shelter formation and visibility is high, although extensive areas of talus slope, areas on the top of the escarpment, creek banks and creek erosionfaces were also examined. While numerous rockshelters containing archaeological deposits were located at the base of the escarpment, very little material was observed in open contexts and what there was appeared to be situated in reworked deposits. It is thought that regular flooding and downcutting of Three Moon Creek in the past may have had a negative impact on the preservation of open sites on the valley floors bordering creek margins.

\section{Excavation Summary}

Ten rockshelters in Cania Gorge have been test excavated within a $15 \mathrm{~km}^{2}$ area at the southern end of the gorge (Figure 1): Roof Fall Cave, Big Foot Art Site, Grinding Groove Cave, Boulder 1, Bushranger's Cave, Contact Cave, Fern Tree Pool Shelter, Long Gallery, Picnic Art Site and Road Cave 1. A total of 17 radiocarbon determinations on charcoal samples has been obtained from these sites, revealing an occupational sequence spanning the period from the Last Glacial Maximum 18,000 years ago to the contact period (Appendix B). All are conventional liquid scintillation determinations with the exception of NZA7991 at Grinding Groove Cave, which is an Accelerator Mass Spectrometry (AMS) date. Brief summaries of the excavations are presented below.

\section{Roof Fall Cave}

Roof Fall Cave is a large sandstone shelter located approximately $80 \mathrm{~m}$ south of the recorded Big Foot Art Site (JE:A07) on Cedar Creek (Figure 1). The walls of the shelter exhibit a number of painted motifs and the floor, which covers an area of approximately $40 \mathrm{~m}^{2}$, is dominated by blocks of rapidly-weathering sandstone detached from the ceiling of the shelter. The site has been the subject of excavations in two separate field seasons. The first (Square A) was excavated in September-October 1996, close to the centre of the chamber. It extended to a maximum depth of about $80 \mathrm{~cm}$, where it reached culturally-sterile sediments an undetermined depth above bedrock. A further two pits (Squares B and C) were excavated in July 1997. They were oriented as a trench perpendicular to the rear wall below a rock art panel to try to determine the age of the art by association with excavated ochre. Large quantities of stone artefacts, animal bone and charcoal were recovered, along with some freshwater mussel shell and ochre.

Seven radiocarbon dates have been obtained from Square A spanning from $18,576 \mathrm{cal} \mathrm{BP}$ (Wk-5216) to the present (Appendix B). Analysis of Square A has revealed significant changes in the distribution of cultural material through time. For further details see Eales et al. (this volume; also Eales 1998).

\section{Big Foot Art Site}

Big Foot Art Site is a recorded rock art site (JE:A07) on Cedar Creek (Figure 1). The rockshelter has formed at the base of a dissected sandstone escarpment and has a floor area of approximately $20 \mathrm{~m}^{2}$ within the dripline, dipping slightly towards the front of the shelter. A single $50 \mathrm{~cm} \times 50 \mathrm{~cm}$ test pit (Square I5) was excavated in the January 1996 field season to a maximum depth of $70 \mathrm{~cm}$ before encountering impenetrable roof fall. This small sample was augmented by a further two contiguous $50 \mathrm{~cm} \times 50 \mathrm{~cm}$ test excavations (G6 and G7) dug to bedrock adjacent to the original square in SeptemberOctober 1996. Excavation revealed a cultural assemblage dominated by flaked stone artefacts of diverse lithology, quantities of bone (burnt and unburnt), abundant charcoal, and small amounts of ochre. Four radiocarbon dates are available for the first test excavation, demonstrating occupation spanning from at least $7,787 \mathrm{cal} \mathrm{BP}(W \mathrm{k}-4638)$ to 300 cal BP (Wk-4880; see Appendix B).

After observing significant numbers of stone artefacts on the surface of the talus slope immediately below the shelter entrance, a $50 \mathrm{~cm} \times 50 \mathrm{~cm}$ pit was excavated towards the base of the slope to determine whether any subsurface cultural material existed in this area (the excavation was designated in the field as 'Big Foot Boulder'). The excavation yielded negligible quantities of cultural material and no dates have been obtained from this square. A detailed technological analysis of the lithic assemblage from Square I5 has recently been completed. Detailed results are presented in Westcott, Lilley et al. (this volume; also Westcott 1997). 


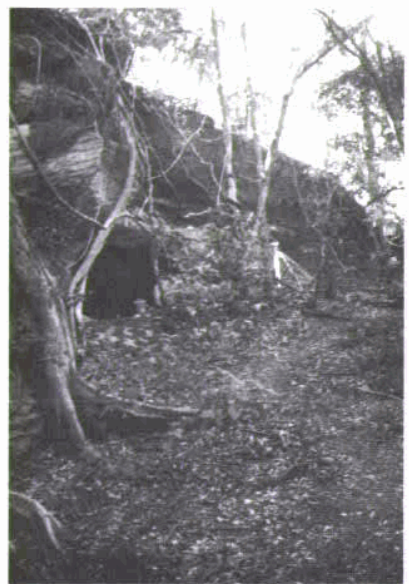

Figure 3. General view of Grinding Groove Cave (Photograph: S. Ulm).

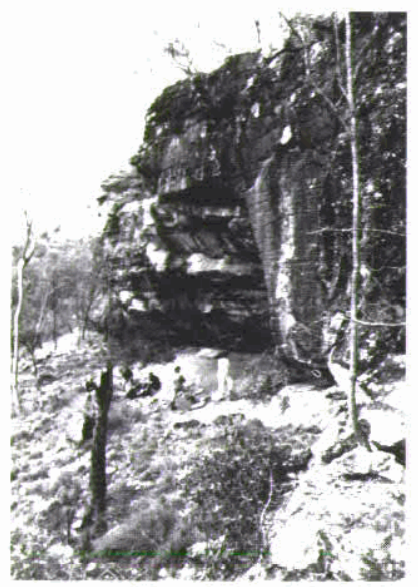

Figure 5. General view of Road Cave 1 (Photograph: S. UIm).

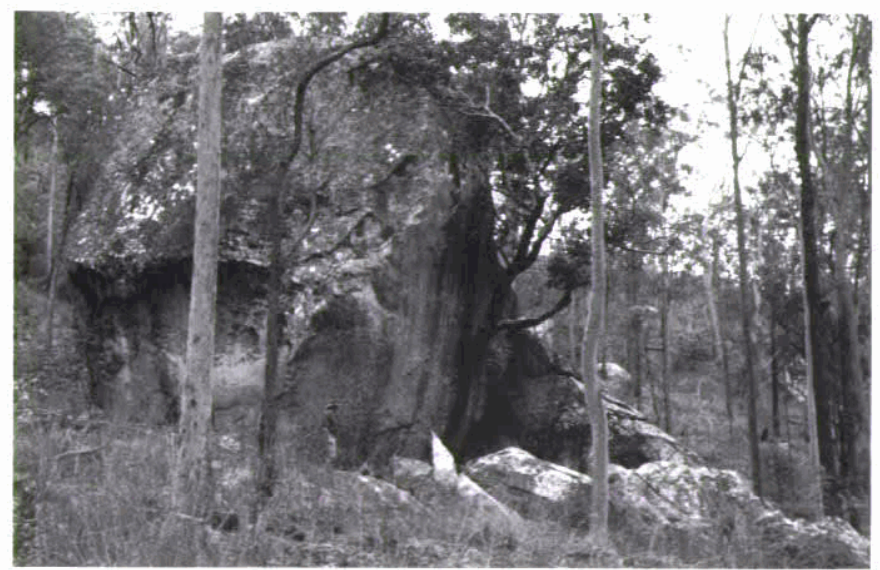

Figure 7. General view of Boulder 1 (Photograph: I. Lilley).

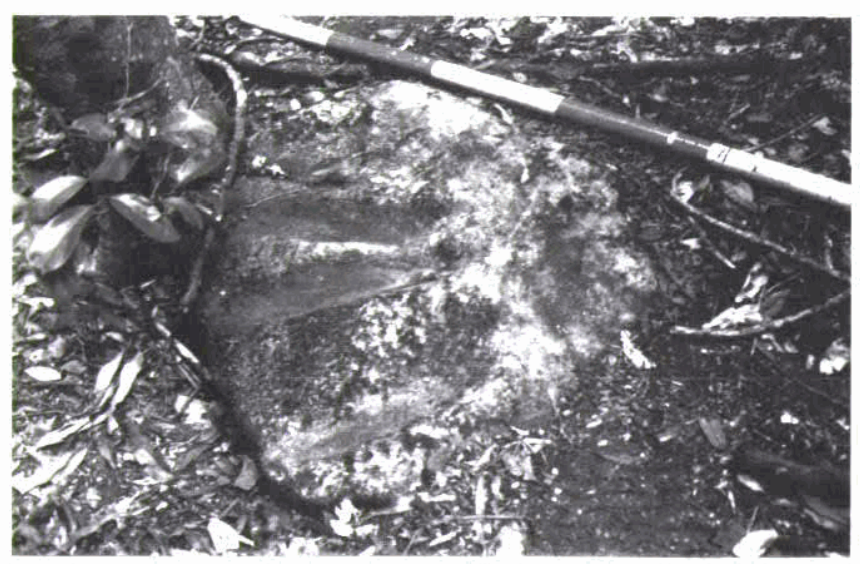

Figure 4. Grinding grooves at Grinding Groove Cave (Photograph: S. UIm).

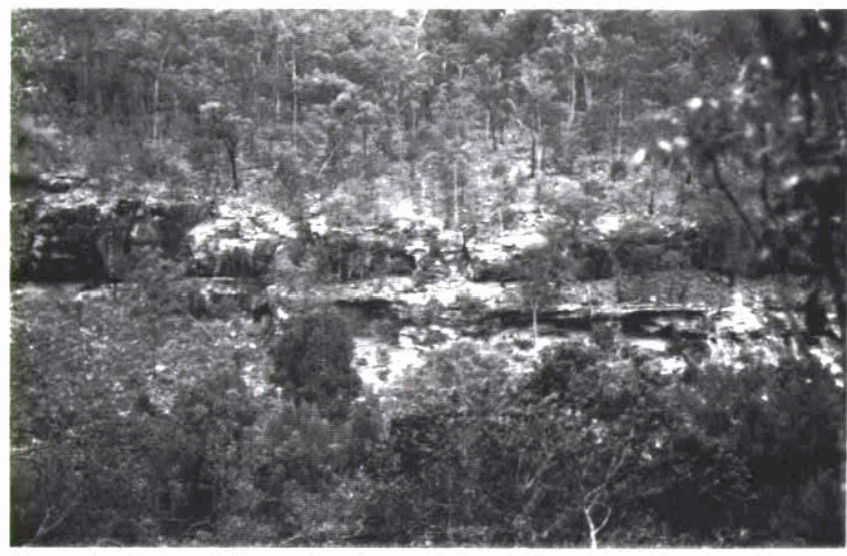

Figure 6. General view of rockshelters at the break of slope along the base of the escarpment. Road Cave 1 is shown on the extreme left of the frame (Photograph: L. Tebble).

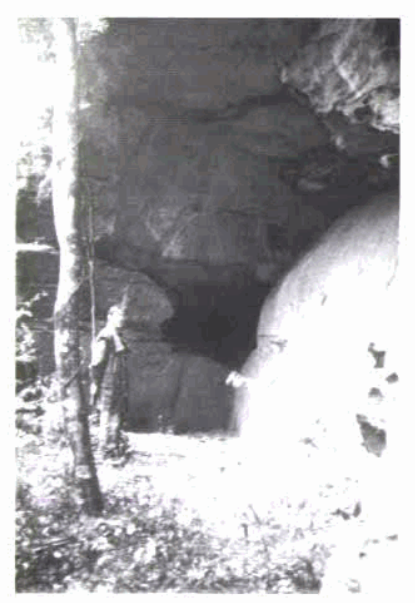

Figure 8. General view of Contact Cave (Photograph: I. Lilley). 


\section{Grinding Groove Cave}

Grinding Groove Cave is located approximately $40 \mathrm{~m}$ north of Three Moon Creek, directly opposite Road Cave 1 (Figures 1, 3-4). Grinding Groove Cave is a relatively small shelter with deposits covering an area of approximately $25 \mathrm{~m}^{2}$ within the dripline. The shelter is joined by a narrow crevice along a fault line in the low escarpment to another shelter exhibiting archaeological deposits about $10 \mathrm{~m}$ to the west (Contact Cave, see below). During initial recording of the site, a number of water-rounded stones exhibiting impact pitting and use-wear (phytolithic polish) were observed around the rear wall of the shelter and one was apparently cached on a small shelf of sandstone at the entrance to a narrow crevice on the western wall of the shelter. Several stone artefacts and whole freshwater mussel shell valves were also noted in the loose surface sediment. Several large pieces of roof fall are evident at the front centre of the shelter at the top of the talus slope, forming a sediment trap for material in the sheiter. Three stones, two within the dripline and one about $5 \mathrm{~m}$ in front of the shelter, exhibit axe grinding grooves.

A single $50 \mathrm{~cm} \times 50 \mathrm{~cm}$ test pit (Square A) was opened in the front centre of the shelter in the JuneJuly 1997 field season to a maximum depth of $70 \mathrm{~cm}$ before excavations ceased owing to the technical difficulty of digging a $50 \mathrm{~cm} \times 50 \mathrm{~cm}$ pit beyond this depth. Excavation revealed a cultural assemblage dominated by flaked stone artefacts of diverse lithology, quantities of bone (burnt and unburnt), abundant charcoal, fragmented and whole freshwater mussel shell and small amounts of ochre. Two discrete hearths were also encountered. A sample of charcoal from a hearth located at the base of the excavations submitted for Accelerator Mass Spectrometry (AMS) dating returned an age of 2,756 cal BP (NZA-7991; see Appendix B).

If this determination accurately dates the hearth it indicates a locally-anomalous feature at the site. Material from a similar depth in Big Foot Art Site and Roof Fall Cave has been dated to 7,787 and 18,576 cal BP respectively, implying that the Grinding Groove Cave deposit accumulated at a much faster rate over the last 3,000 years than other rockshelter deposits in the southern Cania Gorge system. In fact, the rate of accumulation of the deposit (assuming that the surface of all deposits represents $(\mathrm{BP}$ ) is almost 2.5 times faster than the next most rapidlyaccumulating deposit (Road Cave 1, Square B) and almost 6.5 times faster than the entire sequence represented by Roof Fall Cave, Square A (see Lilley et al. 1997).

There is some concern that the date is aberrant, as it may measure the age of intrusive charcoal derived from upper stratigraphic units, possibly moved downwards by extensive wasp burrowing noted throughout the stratigraphic unit above that from which the date was obtained. However, little evidence for insect activity was noted in the stratigraphic unit from which the sample was taken. In addition, the sample is derived from a hearth which appeared to be stratigraphically discrete. The validity of the date could be further tested by dating a whole valve of freshwater mussel shell from an upper unit (e.g. XU9), though dating freshwater mussel has its own problems.

It can also be noted that the archaeological material associated with the date, however, conforms with results from Big Foot Art Site and Roof Fall Cave, where faunal evidence is restricted to about the last 4,000 years. Excavation of Grinding Groove Cave revealed vertebrate and invertebrate faunal material to the base of excavations (see Chicoteau 1998a, 1998b). Further excavations are planned for this site to identify the base of cultural deposits and retrieve samples which should help resolve the dating question.

\section{Road Cave 1}

Road Cave 1 is one of a series of small rockshelters located in a road reserve immediately south of Cania Gorge National Park on the south side of Three Moon Creek, about $1 \mathrm{~km}$ east of the Big Foot Art Site (Figures 1, 5-6). Two $50 \mathrm{~cm} \times 50 \mathrm{~cm}$ test pits (Squares A and B) were excavated to bedrock in January 1996. The excavated assemblage includes many stone artefacts made on a range of raw materials, large quantities of bone, mainly burnt, and some freshwater mussel shell.

Four radiocarbon dates were obtained, three from Square B and one from Square A. The latter and the two uppermost dates from Square B overlap and are thus statistically identical despite the difference in the depths from which the samples were obtained. The bottom date in Square B is substantially older than the other three determinations from the site, though from the same depth below the surface as the date obtained from Square A. The meaning of these results is yet to be fully determined, but there is no reason at this stage to believe that their interpretation will not be straightforward. The ages $928 \mathrm{cal} \mathrm{BP}$ (Wk-4883), $1,067 \mathrm{cal} \mathrm{BP}(\mathrm{Wk}-4882)$ and 2,914 cal BP (Wk-4637) are from Square A, and indicate an earlier phase of slower deposition lies below a later phase in which deposition was more rapid (Appendix B). The date of 1,057 cal BP (Wk-4884) was obtained from the nearby Square B, and is probably indicative of nothing more than the sloping stratigraphy of the deposit, which places material of quite recent age in this pit at the same depth below surface as more ancient material slightly upslope. 


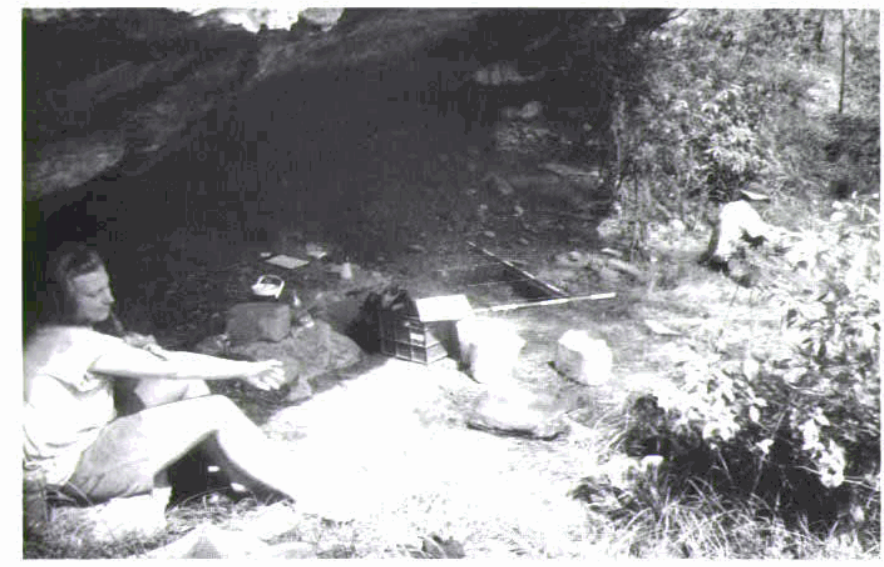

Figure 9. General view of Picnic Art Site (Photograph: S. Ulm).

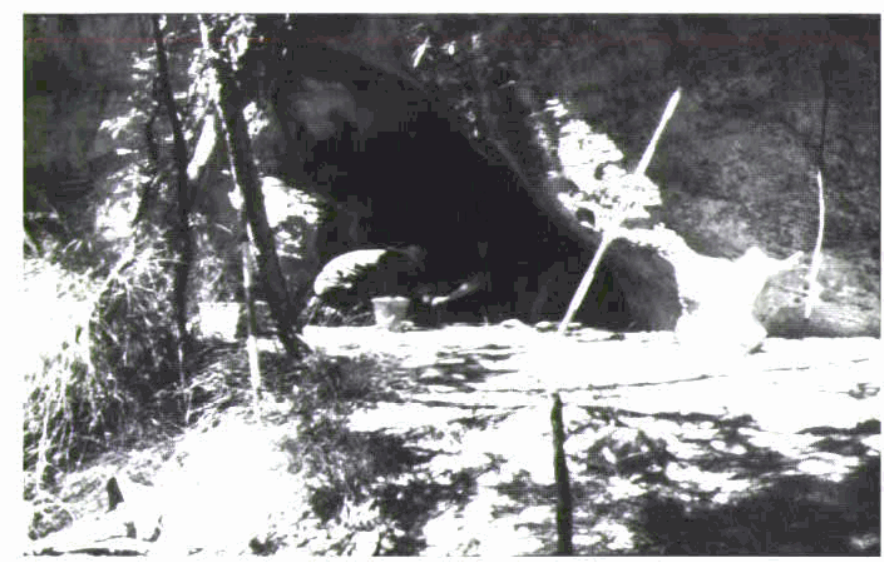

Figure 11. General view of excavations in progress at Bushranger's Cave (Photograph: S. UIm).

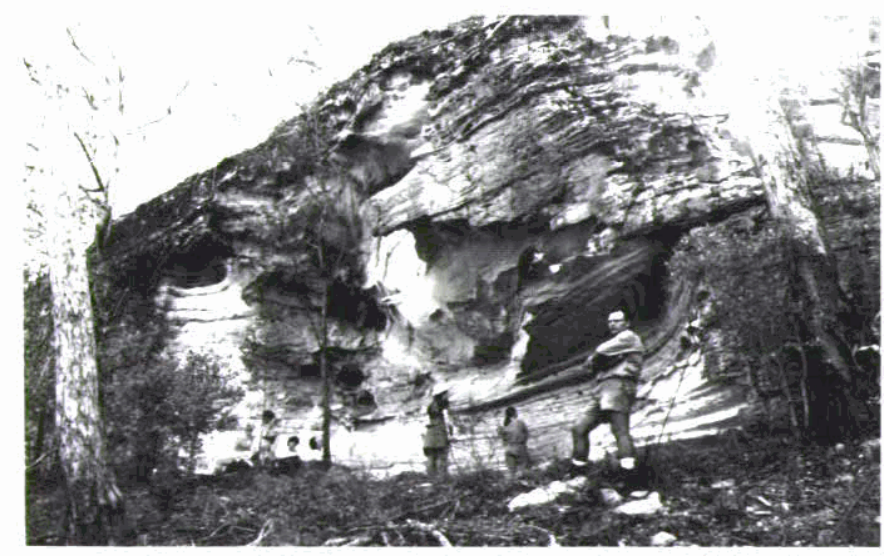

Figure 13. General view of Crevasses Art Site (Photograph: S. Ulm).

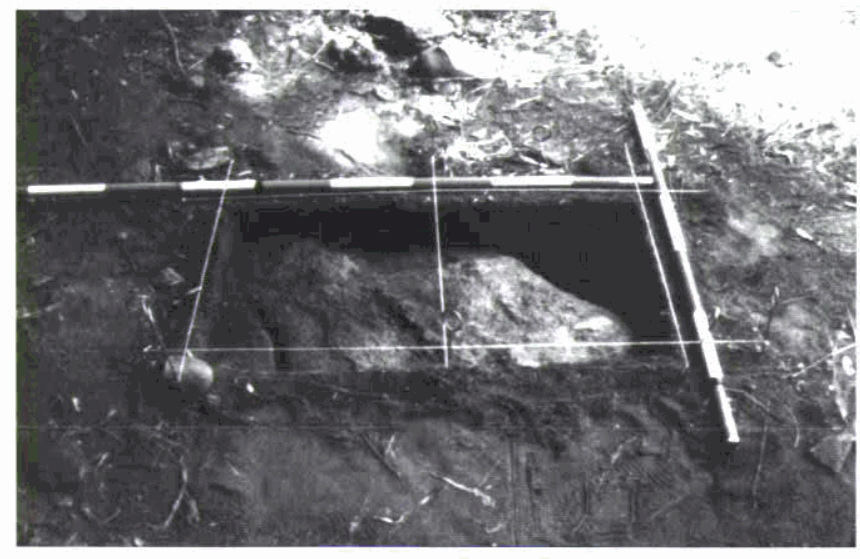

Figure 10. Completed excavation at Picnic Art Site, Squares A and B (Photograph: S. UIm).

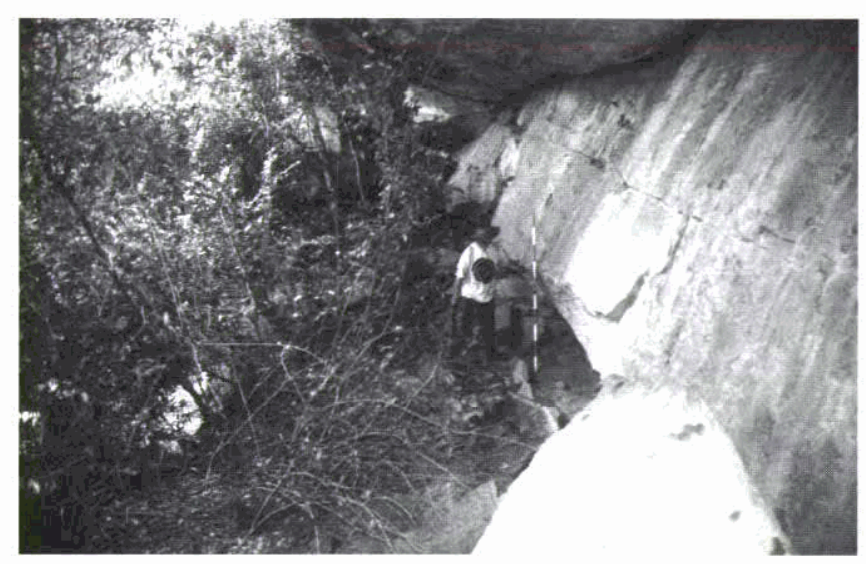

Figure 12. General view of Long Gallery (Photograph: S. Ulm).

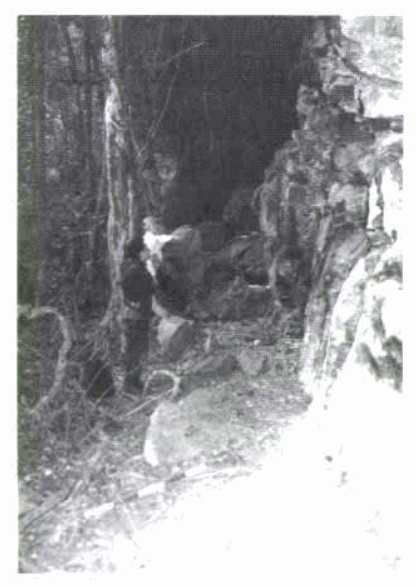

Figure 14. General view of Jamieson's Cave (Photograph: S. Ulm). 


\section{Boulder 1}

The site designated as Boulder 1 is located just north of Gorge Oaky Creek (Figures 1,7). The site consists of two massive boulders which detached from the main escarpment at an unknown time and came to rest against each other to form a sediment trap. Two $50 \mathrm{~cm}$ $x 50 \mathrm{~cm}$ test pits (Squares A and B) were excavated in January 1996, one on each side of the site, to maximum depths of $56 \mathrm{~cm}$ and $34 \mathrm{~cm}$ respectively. Excavation revealed low rates of discard of cultural material, including stone artefacts and bone, and a basal age on charcoal of 3,465 cal BP (Wk-4878; Appendix B).

\section{Contact Cave}

Contact Cave is located on the north side of Three Moon Creek, directly opposite Road Cave 1 (Figures $1,8)$. The name of the rockshelter is derived from the identification of several apparently flaked artefacts made on bottle glass which were found in a recessed area in the extreme west of the shelter. The shelter is $10 \mathrm{~m}$ long and less than $3 \mathrm{~m}$ wide within the dripline, with wide frontage to Three Moon Creek approximately $40 \mathrm{~m}$ to the south. A single $50 \mathrm{~cm} \mathrm{x}$ $50 \mathrm{~cm}$ test pit (Square A) was excavated in July 1997 to a depth of $53 \mathrm{~cm}$ against the rear wall of the shelter. The excavation yielded a diverse assemblage consisting of stone artefacts (including a quartz core), fish bone and scales, freshwater tortoise carapace, freshwater mussel shell, charcoal and bone. These results indicate extensive use of riverine resources in the recent past. No radiometric dates have been obtained for this site. Materials excavated from this site are awaiting full analysis, but it warrants further excavation.

\section{Picnic Art Site}

Picnic Art Site is a small and very low-roofed rockshelter located at the base of the escarpment above the Cania Gorge National Park picnic area on the north side of Three Moon Creek (Figures 1, 9-10). The site contains three small art panels, including two hand prints. Cattle faeces evident on the surface of the deposit suggest that the animals use the shelter for scratching, which may be detrimental to one of the exposed art panels. Layers of white, yellow and red chalky rock are visible in the back of the shelter and it is possible that this material is associated with the production of art. Several water-rounded cobbles were noted on the surface of the rockshelter.

Two contiguous $50 \mathrm{~cm} \times 50 \mathrm{~cm}$ test pits (Squares A and B) were excavated in January 1996 close to the front of the shelter, to a maximum depth of approximately $10 \mathrm{~cm}$ before encountering a large slab of roof fall. Excavations continued for a further $20 \mathrm{~cm}$ in the extreme southwestern corner of Square A, where the edge of the roof fall slab was located. Excavation yielded extremely small samples of cultural material, including a few stone artefacts and some bone. It is possible that more abundant cultural material lies below the roof fall. No radiometric dates have been obtained for this site. Materials excavated from this site are awaiting full analysis, but the site warrants further excavation.

\section{Bushranger's Cave}

Bushranger's Cave is a large, double-chambered rockshelter located on a remote bush walking track in State Forest near the headwaters of Gorge Oaky Creek (Figures 1, 11). Two contiguous $50 \mathrm{~cm} \times 50 \mathrm{~cm}$ test pits (Squares A and B) were excavated in January 1996, to gain access to deep deposits at the site. Very little cultural material was recovered, although some European material was evident in the excavation units immediately below the surface. No radiometric dates have been obtained. Materials excavated from this site are awaiting full analysis.

\section{Long Gallery}

The Long Gallery (also 'The Gallery') is a long, narrow rockshelter located approximately $50 \mathrm{~m}$ west from Picnic Art Site along the base of the escarpment on the north side of Three Moon Creek (Figures 1, 12). No cultural material was observed on the surface of the site, which is dominated by massive blocks of roof fall. A single $50 \mathrm{~cm} \times 50 \mathrm{~cm}$ pit (Square A) was excavated in January 1996 at the rear of the shelter. Although no cultural material was documented during excavation, it is possible that full analysis of the sediments may reveal evidence of human use of the shelter. No radiometric dates have been obtained for this site.

\section{Fern Tree Pool Shelter}

Fern Tree Pool Shelter is a small rockshelter located close to a permanent water hole (Figure 1). The site was selected for test excavation as a grindstone was found on the surface of the deposit. A single $50 \mathrm{~cm} \mathrm{x}$ $50 \mathrm{~cm}$ test pit (Square A) was excavated at the site during January 1996. No cultural material was documented during excavation, but it is possible that full analysis of the sediments may reveal evidence of human use of the shelter. No radiometric dates have been obtained for this site.

\section{Discussion}

This paper has sketched the background to the recent archaeological exploration of Cania Gorge in Central Queensland. The two sites examined most thoroughly at the time of writing are the subject of separate papers in this volume (see Eales et al. this volume; Westcott, Lilley et al. this volume). The remaining 


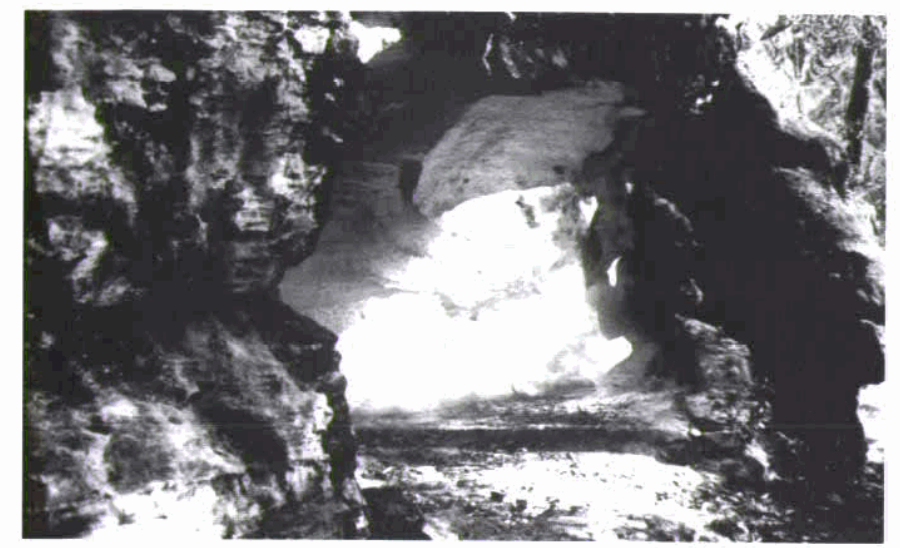

Figure 15. General view of Ranger Art Site (Photograph: S. Ulm).

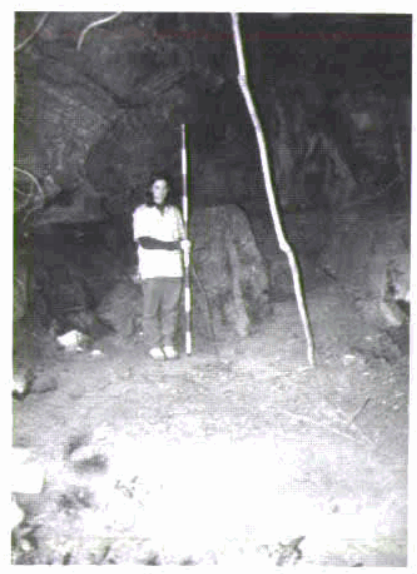

Figure 17. General view of Reid's Cave (Photograph: S. UIm).

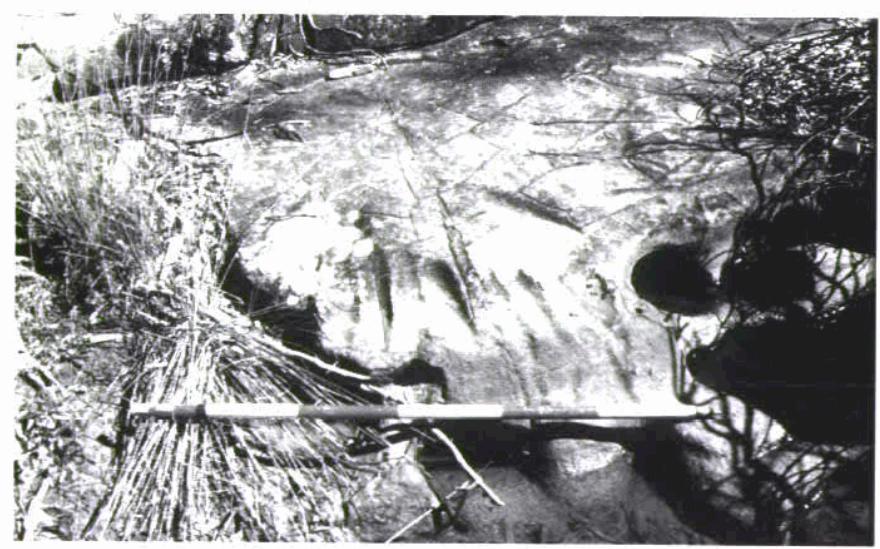

Figure 19. General view of Cedar Creek Grooves 1 (Photograph: S. Ulm).

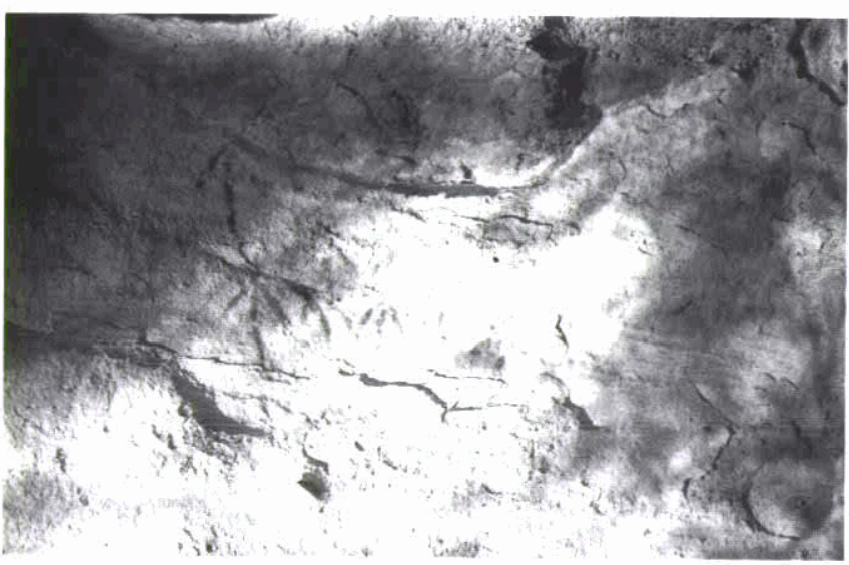

Figure 16. Art panel at Ranger Art Site (Photograph: S. Ulm).

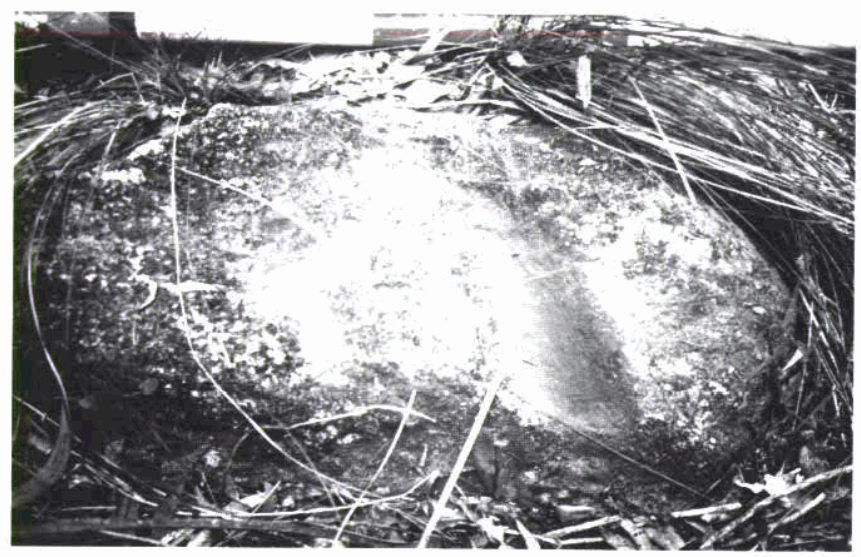

Figure 18. Grinding grooves at Reid's Cave (Photograph: S. Ulm). 
sites that have been test excavated have been described in outline above and will not be revisited in this volume except in passing.

\section{Acknowledgements}

The results reported here are based on research funded primarily by the National Estate Grants Program of the Australian Heritage Commission. Thanks are due to the Gurang Land Council Aboriginal Corporation, the Central Queensland Native Title Claims Unit and the Queensland Environmental Protection Agency for their continued involvement in and support of this research. Paul and Mia Francis of Cania Station have supported the work since its inception. Matthew Jamieson, Karen Gross and the rest of the Jamieson family assisted with their hospitality and participation in the research. Neil Teague and Denis Dray (Queensland National Parks and Wildlife Service) have freely provided advice and assistance throughout the project. We acknowledge the invaluable effort contributed by the following people, without whom the project would not be possible: Hilton (Charlie) Johnson and Ron Johnson (Jr) from the Gurang Land Council; Michael Williams, Chris Clarkson and Deborah Brian from the Aboriginal and Torres Strait Islander Studies Unit; and volunteer field workers Brit Asmussen, Libby Biggs, Nicola Bristed, Melissa Carter, Chris Chicoteau, Malcolm Connelly, Sebastian Crangle, Nick Culbert, Fiona Hutton, Vanessa Krueger, Paul McInnes, Kate Quirk, Jill Reid, John Richter, Gail Robertson, Stephen Skelton, Linda Tebble, Sophie Thompson, Debbie Vale and Nathan Woolford. Tony Eales (Aboriginal and Torres Strait Islander Studies Unit, University of Queensland) provided information and commented on several drafts.

\section{References Cited}

Bard, E., M. Arnold, R.G. Fairbanks and B. Hamelin 1993 ${ }^{230} \mathrm{Th}-{ }^{234} \mathrm{U}$ and ${ }^{14} \mathrm{C}$ ages obtained by mass spectrometry on corals. Radiocarbon 35(1):191-199.

Chicoteau, C. 1998a Two Hundred and Four Kilograms of What?: A Preliminary Site Report of Square A, Grinding Groove Cave, Cania Gorge, Focussing on Sedimentation Rates. Unpublished report submitted for ID232: Independent Project in Aboriginal and Torres Strait Islander Studies I. Brisbane: Aboriginal and Torres Strait Islander Studies Unit, University of Queensland.

Chicoteau, C. 1998b An Analysis of Archaeological Charcoals from Square A, Grinding Groove Cave, Cania Gorge: A Feasibility Study of the Use of Archaeological Charcoals in Cania Gorge Rockshelter Deposits. Unpublished report submitted for ID233: Independent Project in Aboriginal and Torres Strait Islander Studies II. Brisbane: Aboriginal and Torres Strait Islander Studies Unit, University of Queensland.
Clarkson, C., M. Williams, I. Lilley and S. Ulm in prep. Gooreng Gooreng Contemporary Social Landscapes. Aboriginal and Torres Strait Islander Studies Unit Research Report Series. Brisbane: Aboriginal and Torres Strait Islander Studies Unit, University of Queensland.

de Havelland, D.W. 1987 Gold and Ghosts: Queensland Central and South Districts. Sydney: Hyperian Press.

Dear, J. 1959 Geology of the Cania District. Unpublished BSc (Hons) thesis, Department of Geology, University of Queensland, Brisbane.

Denholm, D. 1972 Some Aspects of Squatting in New South Wales and Queensland, 1847-1864. Unpublished $\mathrm{PhD}$ thesis, Australian National University, Canberra.

Eales, T. 1998 Stone Soup: A Residue Analysis of Artefacts from Roof Fall Cave, Cania Gorge, Central Queensland. Unpublished B.A. (Hons) thesis, Department of Anthropology and Sociology, University of Queensland, Brisbane.

Eales, T., C. Westcott, I. Lilley, S. Ulm, D. Brian and C. Clarkson this volume Roof Fall Cave, Cania Gorge: Site report. Queensland Archaeological Research 11.

Horton, D.R. 1994 Gureng Gureng. In D. Horton (ed.), The Encyclopaedia of Aboriginal Australia: Aboriginal and Torres Strait Islander History, Society and Culture, p.442. Vol. 1. Canberra: Aboriginal Studies Press.

I\&WSC 1971 Progress Report Water Resources Investigations Three Moon Creek (Monto Area). Unpublished report to the Irrigation and Water Supply Commission, Brisbane.

Johnston, W.R. 1982 A New Province?: The Closer Settlement of Monto. Brisbane: Boolarong Publications.

Jolly, L. 1994 Gureng Gureng: A Language Program Feasibility Study. Aboriginal and Torres Strait Islander Studies Unit Research Report Series 1. Brisbane: Aboriginal and Torres Strait Islander Studies Unit, University of Queensland.

Lilley, I. and S. Ulm 1995 The Gooreng Gooreng Cultural Heritage Project: Some proposed directions and preliminary results of the archaeological program. Australian Archaeology 41:11-15.

Lilley, I., M. Williams and S. Ulm 1997 The Gooreng Gooreng Cultural Heritage Project: A Report on National Estate Grants Program Research, 1995-1996. 2 vols. Brisbane: Aboriginal and Torres Strait Islander Studies Unit, University of Queensland.

Linick, T.W., A. Long, P.E. Damon and C.W. Ferguson 1986 High-precision radiocarbon dating of bristlecone pine from 6554 to 5350 BC. Radiocarbon 28(2B):943953.

Malcolmson, G.H. 1970 Monto Shire Handbook. Brisbane: Queensland Department of Primary Industries.

Mathew, R.H. 1910 Some rock pictures and ceremonial stones of the Australian Aborigines. Report of the Twelfth Meeting of the Australasian Association for the Advancement of Science Held in Brisbane, 1909 12:493-498. 
Pearson, G.W., B. Becker and F. Qua 1993 High-precision ${ }^{14} \mathrm{C}$ measurement of German and Irish oaks to show the natural ${ }^{14} \mathrm{C}$ variations from 7890 to $5000 \mathrm{BC}$. Radiocarbon 35(1):93-104.

Pearson, G.W. and M. Stuiver 1993 High-precision bidecadal calibration of the radiocarbon time scale, 500-2500 BC. Radiocarbon 35(1):25-33.

Schultz, M. 1994 The Fauna of Kroombit Tops State Forest. Unpublished report to the Queensland Department of Forestry, Brisbane.

Smith, G.K. and D.J. Kent 1993 Understanding and Managing Soils in the Inland Burnett District. Brisbane: Queensland Department of Primary Industries.

Stuiver, M. and G.W. Pearson 1993 High-precision bidecadal calibration of the radiocarbon time scale, AD 1950-500 BC and 2500-6000 BC. Radiocarbon 35(1):1-23.

Stuiver, M. and P.J. Reimer 1993 Extended ${ }^{14} \mathrm{C}$ data base and revised CALIB $3.0{ }^{14} \mathrm{C}$ age calibration program. Radiocarbon 35(1):215-230.

Tindale, N. 1974 Aboriginal Tribes of Australia. Berkeley:
University of California Press.

Ulm, S. and I. Lilley 1996 The Gooreng Gooreng Cultural Heritage Project and Repatriation of the Burnett River Engravings. WAC (World Archaeological Congress) News (Indigenous Focus) 4(1):iii-iv.

Walsh, G.L. 1984 Managing the Archaeological Sites of the Sandstone Belt. Rockhampton: Central Queensland Aboriginal Corporation for Cultural Activities and the Queensland National Parks and Wildlife Service.

Westcott, C. 1997 A Technological Analysis of the Stone Assemblage from Big Foot Art Site, Cania Gorge. Unpublished B.A. (Hons) thesis, Department of Anthropology and Sociology, University of Queensland, Brisbane.

Westcott, C., I. Lilley, S. Ulm, C. Clarkson and D. Brian this volume Big Foot Art Site, Cania Gorge: Site report. Queensland Archaeological Research 11.

Williams, M. 1981 Traditionally, my country and its people. Unpublished MPhil (Qualifying) report, Griffith University, Brisbane. 
Appendix A. List of Sites Recorded and Investigated at Cania Gorge.

\begin{tabular}{|c|c|c|c|c|}
\hline Site ID & Site Type/Name & Recorder & Location & Description \\
\hline $\begin{array}{l}\text { JE:A07 } \\
\text { CG1 }\end{array}$ & $\begin{array}{l}\text { Rockshelter } \\
\text { Big Foot Art Site }\end{array}$ & $\begin{array}{l}\text { J. Pratt } \\
\text { G. Miller }\end{array}$ & $\begin{array}{l}7263900 \\
296900\end{array}$ & $\begin{array}{l}\text { Rockshelter located on the western side of Cedar Creek. Test } \\
\text { excavated in two seasons in } 1996 \text { with } 3 \times 50 \mathrm{~cm} \times 50 \mathrm{~cm} \text { pits. Basal } \\
\text { date of } 7,787 \text { cal BP (Wk- } 4638 \text { ). Shelter contains rock art executed } \\
\text { in red and yellow freehand style. }\end{array}$ \\
\hline CG2 & $\begin{array}{l}\text { Rockshelter } \\
\text { Boulder } 1\end{array}$ & I. Lilley & $\begin{array}{l}7265850 \\
294550\end{array}$ & $\begin{array}{l}\text { Small overhang and sediment trap formed at the base of two large } \\
\text { boulders. Scattered stone artefacts on surface. Date of } 3,465 \text { cal BP } \\
\text { (Wk-4878) (Figure } 7 \text { ). }\end{array}$ \\
\hline CG3 & $\begin{array}{l}\text { Rockshelter } \\
\text { Boulder } 2\end{array}$ & I. Lilley & $\begin{array}{l}7265875 \\
294400\end{array}$ & $\begin{array}{l}\text { Small overhang and sediment trap formed at the base of a large } \\
\text { boulder. Scattered stone artefacts on surface. }\end{array}$ \\
\hline CG4 & $\begin{array}{l}\text { Rockshelter } \\
\text { Boulder } 3\end{array}$ & I. Lilley & $\begin{array}{l}7266137 \\
294975\end{array}$ & $\begin{array}{l}\text { Small overhang and sediment trap formed at the base of a large } \\
\text { boulder. Scattered stone artefacts on surface. }\end{array}$ \\
\hline CG5 & $\begin{array}{l}\text { Rockshelter } \\
\text { Boulder } 4\end{array}$ & I. Lilley & $\begin{array}{l}7266275 \\
295025\end{array}$ & $\begin{array}{l}\text { Small overhang and sediment trap formed at the base of a large } \\
\text { boulder. Scattered stone artefacts on surface. }\end{array}$ \\
\hline CG6 & $\begin{array}{l}\text { Rockshelter } \\
\text { Bushranger's Cave }\end{array}$ & I. Lilley & $\begin{array}{l}7266438 \\
291675\end{array}$ & $\begin{array}{l}\text { Large double-chambered cave-exhibiting European artefacts on } \\
\text { surface. Sparse cultural material revealed through excavation (Figure } \\
\text { 11). }\end{array}$ \\
\hline CG7 & $\begin{array}{l}\text { Axe Grinding Locality } \\
\text { Cedar Creek Grooves } 1\end{array}$ & I. Lilley & $\begin{array}{l}7262675 \\
294825\end{array}$ & $\begin{array}{l}\text { Ten linear ground grooves on flat sandstone creek bed at the } \\
\text { headwaters of Cedar Creek (main branch) (Figure 19). }\end{array}$ \\
\hline CG8 & $\begin{array}{l}\text { Axe Grinding Locality } \\
\text { Cedar Creek Grooves } 2\end{array}$ & I. Lilley & $\begin{array}{l}7262525 \\
295450\end{array}$ & $\begin{array}{l}\text { Ground grooves on a flat sandstone creek bed at the headwaters of } \\
\text { the southern tributary of Cedar Creek. }\end{array}$ \\
\hline CG9 & $\begin{array}{l}\text { Rockshelter } \\
\text { Contact Cave }\end{array}$ & I. Lilley & $\begin{array}{l}7264250 \\
297725\end{array}$ & $\begin{array}{l}\text { Rockshelter on northern side of Three Moon Creek. Scattered bottle } \\
\text { glass, sawn timber, freshwater mussel shell and occasional stone } \\
\text { artefacts on surface. Excavations yielded a well-preserved and } \\
\text { diverse faunal assemblage and some stone artefacts (Figure 8). }\end{array}$ \\
\hline $\begin{array}{l}\text { JE:A25 } \\
\text { CG10 }\end{array}$ & $\begin{array}{l}\text { Rockshelter } \\
\text { Crevasses Art Site }\end{array}$ & & $\begin{array}{l}7268200 \\
292100\end{array}$ & $\begin{array}{l}\text { Large sandstone overhang on the western side of Cania Gorge and } \\
\text { on the western side of the range. All paintings are freehand in red } \\
\text { ochre. Most of the paintings are fading due to weathering of the } \\
\text { sandstone (Figure 13). }\end{array}$ \\
\hline CG11 & $\begin{array}{l}\text { Rockshelter } \\
\text { Fern Tree Pool Shelter }\end{array}$ & I. Lilley & $\begin{array}{l}7263800 \\
294925\end{array}$ & $\begin{array}{l}\text { Small rockshelter located close to permanent water with water- } \\
\text { rounded cobble on surface. Excavation yielded no subsurface } \\
\text { cultural material. }\end{array}$ \\
\hline CG12 & $\begin{array}{l}\text { Artefact Scatter } \\
\text { Giant's Chair Scatter }\end{array}$ & I. Lilley & $\begin{array}{l}7264075 \\
295825\end{array}$ & $\begin{array}{l}\text { Low density scatter of stone artefacts manufactured on various raw } \\
\text { materials noted at Giant's Chair and for } 1.5 \mathrm{~km} \text { along track to this } \\
\text { point. }\end{array}$ \\
\hline CG13 & $\begin{array}{l}\text { Rockshelter } \\
\text { Grinding Groove Cave }\end{array}$ & I. Lilley & $\begin{array}{l}7264260 \\
297820\end{array}$ & $\begin{array}{l}\text { Rockshelter located near the east entrance to Cania Gorge on the } \\
\text { north side of Three Moon Creek with artefacts and freshwater mussel } \\
\text { shell on surface. Excavated in 1997. Non-basal AMS date of a hearth } \\
\text { at c. } 70 \mathrm{~cm} \text { of } 2,756 \mathrm{cal} \text { BP (NZA-7991) (Figures 3-4). }\end{array}$ \\
\hline CG14 & $\begin{array}{l}\text { Rockshelter } \\
\text { Jamieson's Cave }\end{array}$ & I. Lilley & $\begin{array}{l}7264375 \\
297475\end{array}$ & $\begin{array}{l}\text { Large rockshelter located near the east entrance to Cania Gorge on } \\
\text { the north side of Three Moon Creek with three unmodified water- } \\
\text { rounded cobbles on surface (Figure 14). }\end{array}$ \\
\hline CG15 & $\begin{array}{l}\text { Rockshelter } \\
\text { Long Gallery }\end{array}$ & I. Lilley & $\begin{array}{l}7265650 \\
296180\end{array}$ & $\begin{array}{l}\text { Large rockshelter located on the north side of Three Moon Creek. } \\
\text { Test excavated in } 1996 \text { yielding no definite evidence of human } \\
\text { activity (Figure 12). }\end{array}$ \\
\hline CG16 & $\begin{array}{l}\text { Rockshelter } \\
\text { Manuport Cave }\end{array}$ & I. Lilley & $\begin{array}{l}7264400 \\
297550\end{array}$ & $\begin{array}{l}\text { One small grey-coloured manuport located in a small sloping shelter } \\
\text { near the east entrance to Cania Gorge on the north side of Three } \\
\text { Moon Creek. }\end{array}$ \\
\hline CG17 & $\begin{array}{l}\text { Rockshelter } \\
\text { Picnic Art Site }\end{array}$ & I. Lilley & $\begin{array}{l}7265480 \\
296180\end{array}$ & $\begin{array}{l}\text { Small rockshelter with three small art panels. Excavation in } 1996 \\
\text { yielded small quantities of stone artefacts and bone (Figures 9-10). }\end{array}$ \\
\hline
\end{tabular}


Appendix A. List of Sites Recorded and Investigated at Cania Gorge (continued).

\begin{tabular}{|l|l|l|l|l|}
\hline Site ID & \multicolumn{1}{|c|}{ Site Type/Name } & Recorder & Location & \multicolumn{1}{|c|}{ Description } \\
\hline CG18 & $\begin{array}{l}\text { Rockshelter } \\
\text { Ranger Art Site }\end{array}$ & I. Lilley & $\begin{array}{l}7264200 \\
296275\end{array}$ & $\begin{array}{l}\text { Small overhang with seven 'trident' motifs executed in brown-red } \\
\text { pigment (Figures 15-16). }\end{array}$ \\
\hline CG19 & $\begin{array}{l}\text { Rockshelter } \\
\text { Reid's Cave }\end{array}$ & I. Lilley & $\begin{array}{l}7263310 \\
296930\end{array}$ & $\begin{array}{l}\text { Large rockshelter on just outside the Natjonal Park boundary to the } \\
\text { southwest of Roof Fall Cave, on the east side of Cedar Creek. } \\
\text { Surface exhibits a hearth, scattered stone artefacts, bone and } \\
\text { grinding grooves (Figures 17-18). }\end{array}$ \\
\hline CG20 & $\begin{array}{l}\text { Rockshelter } \\
\text { Road Cave 1 }\end{array}$ & I. Lilley & $\begin{array}{l}7264100 \\
297675\end{array}$ & $\begin{array}{l}\text { One of a series of small rockshelters yielding a dense assemblage of } \\
\text { bone, charcoal, stone and shell. Basal date of 2,914 cal BP (Wk- } \\
4637) \text { (Figures 5-6). }\end{array}$ \\
\hline CG21 & $\begin{array}{l}\text { Rockshelter } \\
\text { Road Cave 2 }\end{array}$ & I. Lilley & $\begin{array}{l}7264100 \\
297625\end{array}$ & $\begin{array}{l}\text { One of a series of small rockshelters with bone, charcoal, stone and } \\
\text { shell visible on the surface of the shelter deposit (Figure 6). }\end{array}$ \\
\hline CG22 & $\begin{array}{l}\text { Rockshelter } \\
\text { Roof Fall Cave }\end{array}$ & I. Lilley & $\begin{array}{l}7263920 \\
296900\end{array}$ & $\begin{array}{l}\text { Large rockshelter with some art. Rich assemblage of stone, bone, } \\
\text { shell and charcoal dated to at least 18,576 cal BP (Wk-5216). }\end{array}$ \\
\hline CG23 & $\begin{array}{l}\text { Rockshelter } \\
\text { White Cave }\end{array}$ & I. Lilley & $\begin{array}{l}7266100 \\
293025\end{array}$ & $\begin{array}{l}\text { Small overhang with faded fish painting on degrading sandstone } \\
\text { surface. }\end{array}$ \\
\hline
\end{tabular}


Appendix B. Radiocarbon Dates from Excavated Sites in Cania Gorge.

\begin{tabular}{|c|c|c|c|c|c|c|c|c|c|c|c|}
\hline Site & Square & $\mathbf{X U}$ & $\begin{array}{c}\text { Depth } \\
\text { (cm) }\end{array}$ & Lab. No. & $\begin{array}{c}\text { Weight } \\
\text { (g) }\end{array}$ & $\begin{array}{l}\mathrm{d}^{14} \mathrm{C} \\
(\% o)\end{array}$ & $\begin{array}{l}\delta^{13} \mathrm{C} \\
(\% o)\end{array}$ & $\begin{array}{l}D^{14} \mathrm{C} \\
(\% \circ)\end{array}$ & \% Modern & ${ }^{14} \mathrm{C}$-Age & Calibrated Age/s ${ }^{n}$ \\
\hline Boulder 1 & B & 21 & $29-31$ & Wk-4878 & 9.4 & $-336.2 \pm 3.8$ & $-26.1 \pm 0.2$ & $-336.2 \pm 4.6$ & $66.4 \pm 0.5$ & $3290 \pm 60$ & $3625(3465) 3354$ \\
\hline Big Foot Art Site & I5 & $4 \mathrm{~A}$ & $3-7$ & Wk-4880 & 15.5 & $-41.0 \pm 4.5$ & $-25.5 \pm 0.2$ & $-40.1 \pm 5.5$ & $96.0 \pm 0.6$ & $330 \pm 50$ & $474(306) 0^{*}$ \\
\hline Big Foot Art Site & I5 & $6 \mathrm{~A}$ & $7-10$ & Wk-4881 & 9.0 & $-72.1 \pm 4.3$ & $-25.4 \pm 0.2$ & $-71.3 \pm 5.2$ & $92.9 \pm 0.5$ & $590 \pm 50$ & $646(542) 506$ \\
\hline Big Foot Art Site & I5 & $20 \mathrm{~B}$ & $34-37$ & Wk-4879 & 11.1 & $-405.6 \pm 3.6$ & $-25.8 \pm 0.2$ & $-404.8 \pm 4.3$ & $59.5 \pm 0.4$ & $4170 \pm 60$ & $4834(4802,4771,4609,4587,4574) 4442$ \\
\hline Big Foot Art Site & 15 & 36 & $65-68$ & Wk-4638 & 13.9 & $-584.7 \pm 2.9$ & $-26.4 \pm 0.2$ & $-583.5 \pm 3.6$ & $41.7 \pm 0.4$ & $7040 \pm 70$ & $7923(7787) 7640$ \\
\hline Grinding Groove Cave & A & 21 & 68.29 & NZA7991 & 0.6 & $-289.6 \pm 6$ & $-25.9 \pm 0.2$ & $-288.3 \pm 6.1$ & $71.17 \pm .61$ & $2686 \pm 69$ & $2864(2756) 2548$ \\
\hline Road Cave I & $A$ & 12 & $28-32$ & Wk-4884 & 4.0 & $-137.4 \pm 5.5$ & $-25.6 \pm 0.2$ & $-136.5 \pm 6.7$ & $86.4 \pm 0.7$ & $1180 \pm 70$ & $1232(1057) 927$ \\
\hline Road Cave I & $\mathrm{B}$ & 6 & $7-8$ & Wk-4883 & 17.4 & $-124.0 \pm 4.9$ & $-26.3 \pm 0.2$ & $-121.7 \pm 6.0$ & $87.8 \pm 0.6$ & $1040 \pm 60$ & $1052(928) 771$ \\
\hline Road Cave I & B & 10 & $13-14$ & Wk-4882 & 17.2 & $-141.1 \pm 4.3$ & $-25.4 \pm 0.2$ & $-140.5 \pm 5.3$ & $86.0 \pm 0.5$ & $1220 \pm 50$ & $1232(1067) 965$ \\
\hline Road Cave I & B & 16 & $27-32$ & Wk-4637 & 15.8 & $-300.0 \pm 3.8$ & $-25.5 \pm 0.2$ & $-299.4 \pm 4.7$ & $70.1 \pm 0.5$ & $2860 \pm 60$ & $3076(2925,2914,2884) 2776$ \\
\hline Roof Fall Cave & A & 6 & 11.7 & Wk-5596 & 1.6 & $0.0 \pm 12.1$ & $-26.4 \pm 0.2$ & $2.8 \pm 14.8$ & $100.3 \pm 1.5$ & $>$ Modern & Modern \\
\hline Roof Fall Cave & A & 10 & $14.5-15.5$ & Wk-5597 & 2.7 & $-73.9 \pm 6.8$ & $-25.3 \pm 0.2$ & $-73.4 \pm 8.3$ & $92.7 \pm 0.8$ & $610 \pm 80$ & $665(547) 485$ \\
\hline Roof Fall Cave & A & 12 & $17-19.5$ & Wk-5598 & 2.6 & $-85.7 \pm 7.7$ & $-25.4 \pm 0.2$ & $-85.1 \pm 9.4$ & $91.5 \pm 0.9$ & $710 \pm 90$ & $733(650) 516$ \\
\hline Roof Fall Cave & A & 20 & $28-30$ & Wk-5599 & 1.5 & $-378.2 \pm 9.3$ & $-27.7 \pm 0.2$ & $-374.8 \pm 11.3$ & $62.5 \pm 1.1$ & $3770 \pm 150$ & $4513(4084,4020,4012) 3649$ \\
\hline Roof Fall Cave & A & 27 & $43.5-46$ & Wk-5600 & 2.5 & $-584.1 \pm 4.7$ & $-27.1 \pm 0.2$ & $-582.4 \pm 5.7$ & $41.8 \pm 0.6$ & $7010 \pm 110$ & $7947(7729) 7547$ \\
\hline Roof Fall Cave & A & 31 & 55.16 & Wk-6218 & 1.4 & $-616.0 \pm 7.9$ & $-25.2 \pm 0.2$ & $-615.9 \pm 9.6$ & $38.4 \pm 1.0$ & $7690 \pm 210$ & $8984(8405) 7968$ \\
\hline Roof Fall Cave & $A$ & 36 & $69-74$ & $W k-5216$ & 1.3 & $-858.8 \pm 5.3$ & $-25.1 \pm 0.2$ & $-858.7 \pm 6.4$ & $14.1 \pm 0.6$ & $15720 \pm 380$ & $19387(18576) 17814$ \\
\hline
\end{tabular}

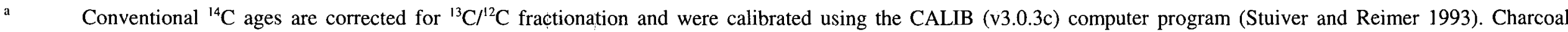
determinations were calibrated using the bi-decal atmosphetic calibration curve using the datasets of Bard et al. (1993), Linick et al. (1986), Pearson et al. (1993), Pearson and Stuiver (1993) and Stuiver and Pearson (1993) with no labotiatory error multiplier. Forty years were subtracted before calibration to correct for ${ }^{14} \mathrm{C}$ variations between northern and southern hemispheres. The calibrated ages reported span the $2 \sigma$ calibrated age-range. 